\title{
The Challenges of Becoming Tutors at Electronic Environments
}

\section{Los retos de llegar a ser tutores de ambientes electrónicos}

\author{
María Eugenia López Hurtado ${ }^{1}$
}

\section{Abstract}

This paper presents a research report of my own experience as a tutor in electronic environments which I have accumulated throughout the guidance for English learners of basic level at a public university. This article looks for illustrating the researcher's own perceptions and challenges as becoming an e-tutor. Therefore, I will introduce an overview of studies and experiences that address this issue in international contexts, and then I will refer to my own experience where I describe the roles that emerged while I was administrating and delivering e- learning pedagogical experiences such as an exploration of some skills and learning activities carried out in an English course; this description embraces three different stages (before, during and after) of implementation. Subsequently, some discussion of the results is provided gathered from the research instruments I used. Finally, some conclusions and suggestions are provided in regards to the research question of the study, its outcomes on how tutors' challenges shape tutor's roles in electronic environments.

\section{Key Words:}

E-Tutors, E-Learning, E-Platforms, E-Environments, E-Learners.

\section{Resumen}

Este artículo presenta una reflexión acerca de mi experiencia como tutora de ambientes virtuales que he acumulado a través de la orientación de un curso de inglés en una universidad pública. El propósito de este artículo es ilustrar las propias percepciones y retos del investigador al convertirse en tutor virtual. De tal modo que presentaré un recuento de estudios y experiencias relacionadas con este asunto en contextos internacionales para posteriormente referirme a mi propia experiencia donde describiré en detalle los roles que surgieron y cómo algunas habilidades y actividades de aprendizaje pueden ser exploradas; esta descripción comprende tres etapas diferentes (antes, durante y después) de la implementación. Continuaré con la discusión de los resultados obtenidos de los instrumentos de investigación que usé y, finalmente, me referiré a algunas conclusiones y sugerencias en relación con la pregunta del estudio y los resultados acerca de cómo los retos asumidos por el tutor moldean sus roles en ambientes virtuales.

\section{Palabras clave}

Tutores virtuales, aprendizaje electrónico, plataformas electrónicas, ambientes virtuales, estudiantes electrónicos/virtuales.

Artículo recibido el 7 de abril de 2014 y aprobado el 20 de agosto de 2014 


\section{Introduction}

After some online courses offered by government and nongovernment institutions, exploring a variety of topics such as web design, computer management, e-tutor development programs, text digitation, ICT tools applied to Education, strengthening of technology in education and how to use both private and open-source virtual platforms, I decided to carry out this innovation in my e-classroom; it was one of the most challenging e-experiences that I have become familiar so far as an e-tutor.

This e-experience was carried out at a public university that was created to supplement face-to-face lessons of a Basic English course of at the Bachelor of Arts program. The intention of this e-experience was to draw attention to the different roles a tutor needs to assume when technology is introduced in class; this is one of the challenges that new and experienced professionals have to face when integrating Information and Communication Technology (ICT). This paper includes a brief introduction, an explanation of the e-learning framework, some tutor roles gained with experience and some suggestions about how to refine these tutor profiles.

The present study aimed to investigate how the challenge of becoming a tutor in an electronic environment shapes the tutor's roles and performance, addressing the following research question: How do challenges tutors face shape their roles when performing in electronic environments?

\section{E-learning framework}

Based on the main purpose of this study -i. e., to illustrate the researcher's own perceptions and challenges as becoming an e-tutor- this section introduces an overview of the main constructs that oriented the analysis and interpretation of data and some research studies related to them. I will start by introducing blended learning then e- learning pedagogy after, the role of the e-tutor, next online training for language courses, succeeding with new challenges for first and second generation L2 tutors, followed by collaborative and cooperative learning.

\section{Blended learning}

For the purpose of this e-experience, blended learning was chosen to carry out activities with e-learners to support face-to-face lessons. This type of e-learning refers to a mixture of online and faceto-face course delivery as quoted by Dudeney and Hockly (2007); for this e-experience, time spent in face-to-face session had an average of $70 \%$ while the other $30 \%$ was dedicated to work on the Blackboard platform, there students met with their tutor once a week during 16 weeks.

\section{E-learning pedagogy}

As the curriculum changes for future educational needs, educators can also foresee that the twentieth century philosophy of education will include Transformative learning, which handles some key concepts related to independent learning, experiential learning, collaborative and cooperative learning tune to provide lifelong learning with appropriate interpersonal, self-reflective, subject-specific and research skills as being stated by Maier and Warren (2000).

\section{Transformative learning}

The concept of transformative learning has been a topic of research and theory in the field of adult education; Taylor (1998) believes that too much emphasis has been placed on the role of the teacher at the expense of the participant, who also has to assume responsibility for creating the learning environment so transformative learning can occur. During the last two decades, transformative learning has evolved "into a comprehensive and complex description of how learners construct, validate, and reformulate the meaning of their experience" (Cranton 1994, p. 22 cited by Imel, 1998).

Some of the features of transformative learning are embedded in the figure 1 below: it represents different types of learning (independent learning, experiential learning, collaborative and cooperative learning) that are part of e-learning environments, especially in e-platforms experiences. 
Figure 1. Features of Transformative Learning

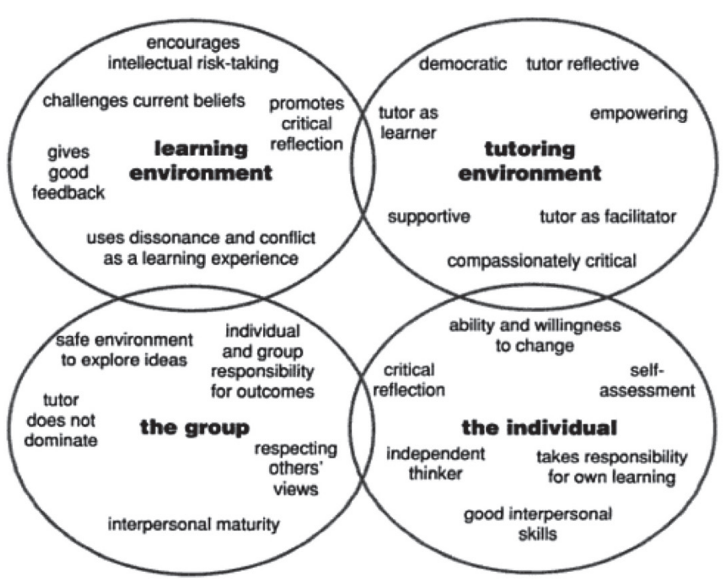

Source: Taken from Maier \& Warren (2000, p. 12).

From transformative learning, which is the philosophy of education that underlies e-learning experiences, it is necessary to deal with three types of learning are experiential learning, collaborative learning and cooperative learning that were fundamental in this e-experience.

Experiential learning considers learning as "the process whereby knowledge is created through the transformation of experience. Knowledge results from the combination of grasping and transforming experience" (Kolb, 1984, p. 41). In other words, experiential learning can apply the knowledge they have gained from previous experiences and add to it through new experiences such as role play, problem solving, and work experience. Kolb's cycle (1984) explains how the elements of the program can shape learning.

In experiential learning information and experience are owned and changed by individuals as it is seen in Kolb's cycle, figure 2. Only when they own that knowledge, is it said that learning occurs.
Figure 2. Kolbs' cycle

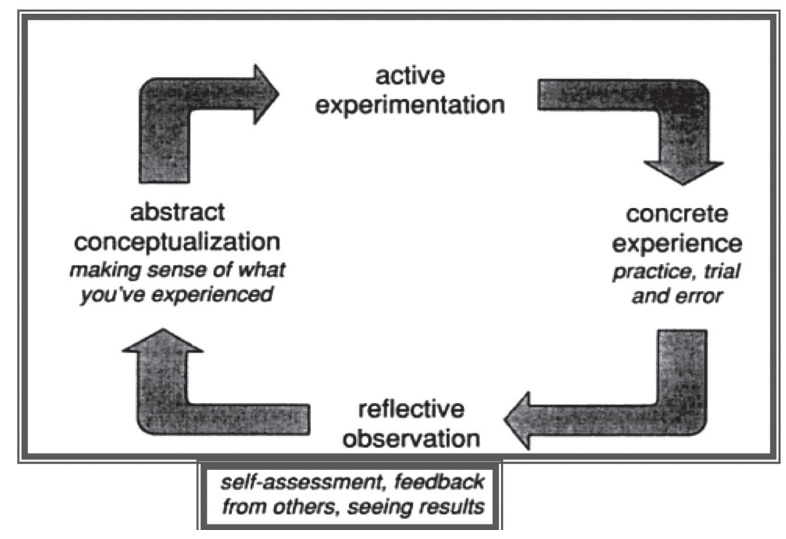

Source: Taken from Maier \& Warren (2000, p. 15).

\section{The role of the e-tutor}

The role of the tutor is fundamental in electronic environment because there is a strong dependence of success in the various roles that are assumed by the tutor as presented by (Goold, Coldwell and Craig, 2010) as shown in figure 3 who also cited the European Union E-tutor project (Directorate-General for Education and Culture, 2004-2005) which developed a model for e-tutoring that incorporates the relationships between the various roles, where electronic technologies have increasingly changed the interaction between instructors and student.

Figure 3. Roles of E-tutors

\section{E-tutor roles}

1. Content facilitator

2. Metacognition facilitator

3. Process facilitator

4. Advisor/counsellor

5. Assessor

6. Technologist

7. Resource provider

Source: Goold, Coldwell and Craig (2010, p. 706.) 


\section{Online training for language courses}

It is understood that both novice and experienced tutors face some factors that intervene in their work in electronic environments on a daily basis, as specified by Stickler and Hampel (2007). These include new content, accessing the Web and a tendency to be even more up-to-date; new media, as rapid software developments allow for new ways of interaction; and, consequently, a new pedagogy that harnesses the new media for learning and teaching. I completely agree with their statement since their recommendations are to be kept in mind if tutors in electronic environments decide to continue exploring their learning and teaching practices with technology support. Along these factors (Stickler and Hampel, 2007) also state that tutors face both technological and pedagogical challenges; these important aspects of training make tutors feel more confident in choosing, evaluating, adopting and even creating material. These features add another component that (Stickler and Hampel, 2007) also explain which is to introduce those differences between teaching languages in an online medium and teaching in a traditional classroom; these differences are not only based on tasks and material design but also teaching style and pedagogy. This confirms that tutors need to balance their training in both areas, which complements their integral role and provides confidence to their learners.

\section{New challenges for first and second generation L2 tutors}

As technology and pedagogy evolve, first and second generation tutors face new challenges. I have to say that at this point in my academic life I feel confident about the experience I have gained through years working in electronic environments; conducting blended learning courses has given me confidence as an e-tutor and course designer. Decisions I made when designing my course and how to deliver it were important factors that made me feel part of the first tutor generation. In contrast, second generation L2 tutors, as stated by Nissena and Tea (2012) in their study of new challenges for second generation $\mathrm{L} 2$ tutors trouble understanding the function of the online part of the courses, and their own role within this online part. This second generation of tutors did not design the course, which considerably affected their role as e-tutors; they felt much more confidence in the face-to-face course modality. The suggestions that are given in their conclusions are relevant to new tutors who want to refine their roles when they assume the responsibility of conducting blended or online courses; they conclude that the new generation of tutors needs to be integrated into a team of peers or course coordinators which feels at ease with technology, takes initiatives within the course and feels capable of influencing course design.

\section{Collaborative and cooperative learning}

This is an essential element of communicative learning within the transformational philosophy pointed out by Maier and Warren (2000). Although each method has a different purpose one is more controlled by teachers than the other; both are good examples of developing interpersonal skills, teamwork and independent learning. When using technology in teaching and learning, both approaches play a significant role, especially in asynchronous communication.

\section{Research Design}

The case study presented here is aimed at understanding how the researcher's own perceptions and challenges make sense as becoming an e-tutor. As cited by (Merriam, 1988) a qualitative case study is "an intensive, holistic description and analysis of a single instance, phenomenon, or social unit" (p. 9). This method provided me with a rich view of the data collected in order to interpret and reflect about the challenges tutors face in electronic environments and how those challenges shaped their roles when performing in electronic environments.

\section{Participants' background}

This study involved students from a Bachelor of Arts program in English at public university. They studied their first semester and this research was 
based on the course called Basic English I of their major. There were 22 participants 12 of them were female and 10 male their ages ranged from 15 to 18 years old. At this point of implementing none of them had any training of Blackboard Platform and they were oriented by their tutor on this platform to support learners' online performances.

\section{Research instruments and procedures}

Participants were asked to deal with three different kinds of instruments as a way to triangulate and validate data to succeed in the study's findings and conclusions. An Initial Survey (IS) that learners answered was based on their previous experiences with technology; it was applied before the tutor implemented her pedagogical intervention. This survey not only revealed the students' profile on technology use but also provided further details in making right decisions on E-activities design. The second instrument a Feedback Form (FF) was applied while learners developed e-activities on the platform in order to analyze students' progress in language development and their perception of the designed E-activities and use of the platform. The final instrument was a survey (FS) that was filled out when the experience was concluded, which gathered e-learners final views towards this implementation:

\section{My own experience as an e-tutor}

My attitude towards technology has shaped my performance as an e-tutor in the last decade I have always thought that nobody teaches you at all, you have to assume the responsibility to face the unknown by taking the challenge, and I confirm with an aphorism from Aristotle "Teaching is the highest form of understanding". Therefore, when a technological implementation takes place it is necessary to consider attitudes to technology not only from teachers, but learners as well. At this time, when the pedagogical intervention was carried out I thought it was important to determine where I stand and how important my confidence about using technology in the classroom was. Following this line of thought, I find attitudes to technology very relevant for the current study and I agree with Dunedey, and Hockly's (2007) classification, they identified attitudes in three groups: technophobe, digital native and digital immigrants, shown in the figure 4. From this categorization I find myself in the group of digital immigrants as well as my learners.

I felt fine in all technology sessions, maybe at the beginning, it was difficult to me because I was not used to working with technology, regarding the platform management, I didn't know it well so at the beginning I didn't like this idea of introducing technology in the first sessions. Now I see that it is not complicated. (Student view on technology)

Having a point of departure, I can start with the description of how my role has evolved depending on the sources and needs of my learners in this implementation of technology in the classroom.

Figure 4. Attitudes to technology by Dudeney and Hockly

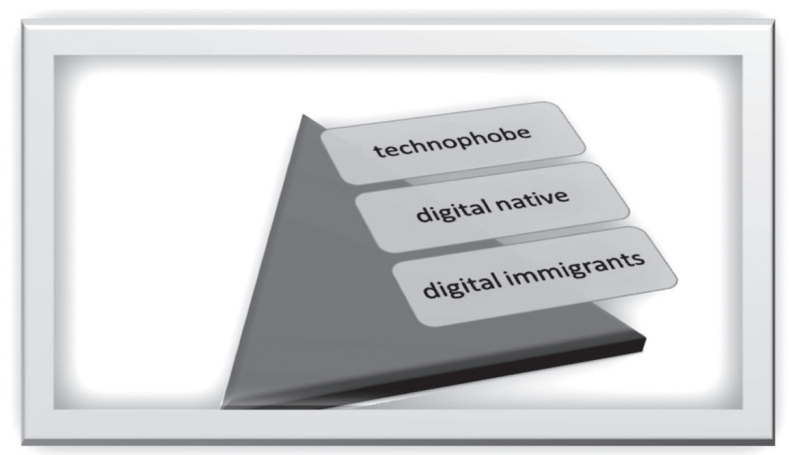

Source: Adapted from Dudeney and Hockly (2007 p. 8).

\section{My challenges as an e-tutor}

As an e-tutor, I need to know that I am not more than the controller of a class; I can play different roles that help e-learners improve in language performance and technology management. As part of this reflection, I saw myself assuming different roles which can be associated with challenges that tutor faces in electronic environments depending on some educational situations that emerge in the implementation, as it is shown in the figure 5: 
Figure 5. E-tutor's roles

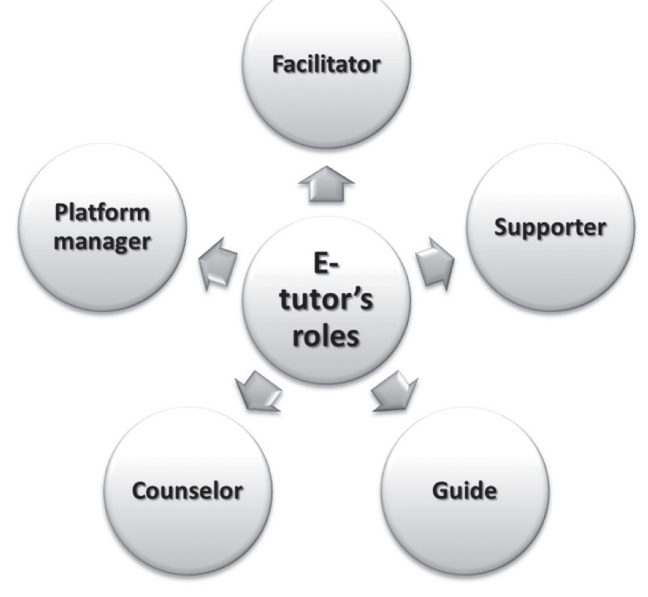

Source: Author.
Platform Manager: You should handle at least basic tools of the platform or technology in use. If you are confident about the use of this technology guidance; your learners will be successful and be certain about the fulfillment of their learning goals. The chart 1 reviews these skills you are invited to refine, objectives and learning activities.

Supporter: Makes explicit the attributes of effective availability, which is a key factor that students' learning processes should count on in this e-learning experience.

An e-tutor needs to be aware of his students' strengths and weaknesses to make the right decisions in regards to material design and course delivery; therefore, in this pedagogical intervention, feedback forms provided me with an insight of how things were going and offered me definite elements to support them in face-to-face sessions or by chat.

Chart 1. Skills, objectives and learners activities tackled by the e-tutor

\begin{tabular}{|c|c|c|}
\hline Skills & Objectives & Learners' activities \\
\hline $\begin{array}{c}\text { Systematization and mana- } \\
\text { gement of information }\end{array}$ & $\begin{array}{c}\text { To provide evidence of assessment } \\
\text { during the process of learning }\end{array}$ & $\begin{array}{c}\text { Analysis, saving and sending } \\
\text { information through platform tools }\end{array}$ \\
\hline $\begin{array}{c}\text { Handling of evaluation } \\
\text { through platform tools }\end{array}$ & To avoid frustration and anxiety & $\begin{array}{c}\text { Evaluation simulations } \\
\text { Evaluation activities }\end{array}$ \\
\hline
\end{tabular}

Source: Author.

Chart 2. Skill, objective and learners activity tackled by the e-tutor

\begin{tabular}{|c|c|c|}
\hline Skill & Objective & Learners' activity \\
\hline Constant feedback & To hear students' voices and needs & Feedback forms \\
\hline
\end{tabular}

Source: Author.

Facilitator: Explores the essential components of making an action or process easy or easier.

Chart 3. Skills, objectives and learners activities tackled by the e-tutor

\begin{tabular}{|c|c|c|}
\hline Skills & Objectives & Learners' activities \\
\hline $\begin{array}{c}\text { Building up of new experiences of } \\
\text { knowledge from previous ones }\end{array}$ & To motivate students to write in English & Meaningful writing activities Design \\
\hline $\begin{array}{c}\text { Expansion of language practi- } \\
\text { ce (communication tools) }\end{array}$ & To gain confidence in the use of English & Speaking and writing activities \\
\hline & Source: Author.
\end{tabular}


Counselor: Assists participants in exploring ways to make their right decisions to overcome technical and learning difficulties:

Chart 4. Skills, objectives and learners activities tackled by the e-tutor

\begin{tabular}{|c|c|c|}
\hline Skills & Objectives & Learners' activities \\
\hline $\begin{array}{c}\text { Awareness about strengths } \\
\text { and weaknesses }\end{array}$ & To make right decisions when necessary & $\begin{array}{c}\text { Demanding and challenging } \\
\text { activities design }\end{array}$ \\
\hline Tips for learning a foreign language & $\begin{array}{c}\text { To be aware of the implications } \\
\text { of studying a foreign } \\
\text { language in our context }\end{array}$ & Learning to learn activities \\
\hline
\end{tabular}

Source: Author.

Guide: Develops an understanding of interaction, the rationale for developing their communication skills and how the continuous practice with other users enhances their confidence of language production. Their constant dialogue with content, provided by work guides, collaborative tasks and conversation with their tutor were examples of this guidance throughout the whole course.

Chart 5. Skill, objectives and learners activities tackled by the e-tutor

\begin{tabular}{|c|c|c|}
\hline Skill & Objective & Learners' activities \\
\hline & To gain confidence in the & Content \\
Importance of interaction & use of language & Partners \\
\hline
\end{tabular}

Source: Author.

\section{Discussion of findings}

This section describes the two main categories that emerged from the data analysed in the study: the first named learning which embraces self-realization, preferences and feelings and the second entitled knowledge: platform, others and independent learning; these previous categories as illustrated in figure 6, confirmed that roles assumed by the tutor were definite in shaping students' English language performance in this electronic experience.

The method of analysis used in this study was based on grounded approach; this approach invites the researcher to read several times the data to notice similar themes or patterns (Freeman, 1998). I wanted to analyze the data and identify the categories that emerged from that analysis.
Figure 6. Categories that emerged from the study

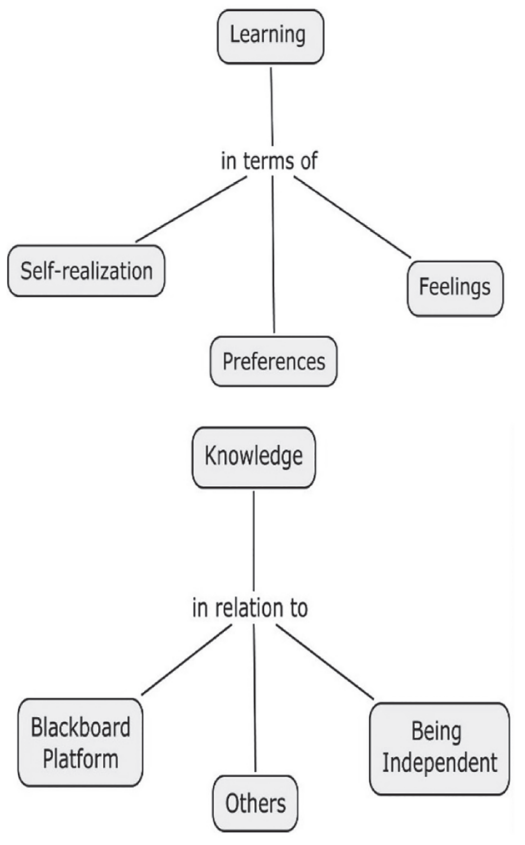

Source: Author. 


\section{Self- realization of new ways to learn}

Based on the variety of roles played by the tutor in this electronic experience, it was found that students' self-realization upon new ways to learn were definite in adopting a new path of learning, such as learning from their own mistakes. Learning from interactive activities delivered in their e-course led them towards the correction of mistakes and learning with fun; they seemed to enjoy this electronic learning experience. Furthermore, their knowledge was broadened; they could learn more about different issues a part from their textbook topics and some structures of the language. Finally, they became aware of some organizational patterns of their time and how to take advantage of meaningful input of practice they had at hand, such as Internet websites. The following opinions exemplify these new ways of learning

I learnt how to organize my time and how to use internet as a great help and complement to do some revision on the English language. E-L1 FF3

I reinforced my knowledge about verbal tenses, structures, I improved my listening, and I learnt new vocabulary. E-L2 FS

I learnt how to handle the digital Drop box on the platform. I learnt phrasal verbs, collocations, and some daily expressions. E-L3 FF7

We could learn English by many different options to make it more interesting... E-L4 FS

This is just what I needed, real conversations. In this way I'm going to learn much more about speaking and listening, moreover the conversations were interesting and understandable. E-L4 FF9

We usually made many mistakes in writing and, speaking, so these kinds of tips were very important for us. It helped me improve my skills. FF10

These electronic sessions were interesting because they explored other ways of learning through online methods, likewise with these sessions we could revise topics that were not clear in class. Another achievement through these sessions was to improve skills such as in listening and reading. EL14FS
The tutor fostered her self-realization on a weekly basis so students became aware of their own decisions to become disciplined enough to achieve personal and professional goals and to administer their time properly.

\section{Learning preferences}

The continuous support and guidance from the tutor led students to work on their learning preferences; the ones they favored more were around authentic sources such as videos, online games, interactive quizzes and listening practices. Therefore, video analysis had a high impact in learners because they made learners improve their comprehension skills; they acquired expressions that they did not usually listen; they also had fun with some online games because they learnt in a didactic way. Interactive quizzes; tested their knowledge, and they really checked what e-learners revised in different sessions of study. Listening practices made them improve their comprehension and they tried to understand native speakers' speech and accents.

I like a lot the program Tell me more because you can see your advance, and there are a lot of interesting activities. EL8FS

GAMES: It was so fun though I wasn't good player I enjoyed this moment, and the best was that I learnt while played. EL22 FS

Watching videos on the web: this activity was very important because it helped us to improve our listening level. EL19FF 10

Many people prefer studying this way. These exercises were dynamic. The practice was essential for English's class. EL7FS

Listening activities were interesting because I could train in listening which I consider the most difficult topic in English learning. EL3 FF11

Video activities let us improve our comprehension and provided us with expressions that we usually did not listen to adding new words to our vocabulary. EL13FS 
Interactive quizzes test your knowledge, besides they let put in practice what you learnt in different class sessions. EL5FF9

Most of the e-learners thought that they were good activities because they complemented topics studied in face to face lessons; some e-learners could go deeper in experience and knowledge; they could learn through a variety of e-activities uploaded on the platform. Besides, most of them enjoyed their work online when they had to submit a test provided by the webpage where they were practicing; some others thought that it was a different way of learning because the technological resource had been very important.

\section{Feelings}

The articulation of the different roles that tutor assumed in this electronic experience provided with positive feelings in favor of technology support to students' learning because most of the e-learners felt well; they had the chance to learn in each session something different. They valued a different way of learning by means of variety. When some e-learners had doubts; they asked their tutor using Gmail's chat or the platform chat. Most of the time, they felt comfortable since they were not accustomed to work in computer labs; although it took a while to be used to them.

I felt good, because I could practice the items learnt in class, and tried my knowledge. EL9FS

I felt very good with that activity, because it was very interesting and important to learn by other way this topic. EL5 FF3

I really liked this part. I looked for the punctuation rules specially and I enjoyed writing about something that I liked. I want to write perfect texts in the near future. EL6FF5

I feel excited for exploring a new way of learning English. EL8FS

I felt that I was learning more and more and that I had to study hardly because I had to improve some things. It was a good activity in all senses.
We needed more exercises like these to improve our skills. EL17FS

In this session I felt very well as I clarified many doubts. EL18FF4

Previous learning self-realization, preferences and feelings provided confidence in their performance and contributed in other areas of knowledge as it is stated as follows:

\section{Knowledge on platform work}

As a platform manager one of the tutor skills I had to manage was knowledge of Blackboard platform. Results from the initial survey provided me with a lot of input regarding no previous experience on students' side about virtual platforms. However, learners seemed to cope with some platform tools while other ones took some more time to handle them. Luckily but the end of this study results were successful because all kinds of e-activities were carried out without problems as it is exemplified in the following students' opinions.

It was a new experience for me today... I had never used one like that. EL5FF 8

I wanted to know more about the forum because I needed to share in. EL3FS

At the beginning of the course was difficult to me because I had a hard time since I was not accustomed to work with technology and regarding the platform, I didn't know anything about it. EL14FF11

I believe the platform was a useful tool in which we practiced all we learnt in a dynamic way. EL21FS

Obviously I learnt little by little the platform use and know to use its tools to study and improve my English knowledge. EL13FF4

Students gained confidence in using Blackboard tools therefore; their language performance had a positive impact in terms of improvement, besides they learnt from their classmates as it is presented as follows. 


\section{Knowledge about others}

Learners understood that this new way of learning provided them with new forms of getting information from others through forum mainly, there, as a platform manager my role was relevant since I guided them on how to exploit this tool; therefore students valued this learning about each other through this tool as it is explained in the following examples from students' views.

Forum: it was a very interesting way to know the classmates and share with them as well as teacher's expectations and all the things that we wanted to know and share with others. EL7F8

To work in groups is a good idea to know our partners. EL1FS

We had the chance of interacting with our partners and learn about group work. EL4FF2

Collaborative work and the use of individual and grouped forums facilitated this knowledge about others. Students realized that through interaction with others they also had the chance to expand their knowledge on language learning and about their classmates. They also believed that previous and current experiences provided them with some tools for further independent language learning practices.

\section{Knowledge about being independent learners}

The reunion of those roles assumed by the tutor such as facilitator, supporter, guide, counselor, and platform manager in this electronic study provided learners with meaningful input to assume a new role as independent learners as it is shown as follows:

...I enjoyed writing about something that I liked. I want to write perfect texts in the near future. EL 7 FF 8

I felt so good and I think this activity is a good idea to learn by myself. EL 3 FS

...Some tips for my future that maybe would be important in special the third and second video (Videos' references: how to use your body lan- guage to improve your presentation and saying sorry). EL 4FF9

I believe there is always something to learn and improve, learning is for our whole life and to remember and review what we studied in class makes we improve what we are lacking, and I think will favor our learning in future. EL2 FS

It would be very good to revise those web sites in the future many times because there was useful information. EL7FS

I need more video and listening activities, I think this is the most important to improve my English. I must practice more, but I feel that I have improved from first time that I did this type of activities. EL16 FF3

I think through listening activities like this I've improved my listening, but I know it's important to continue doing it. EL FF12

I learnt to organize my time and use internet as a help and complement to reinforce my learning. EL15 FF11

Students realized that positive experiences of learning can be explored in future practices because they will help them perform better. Following models of good learning also enhance new practices so students can learn on their own without depending on the teacher's guidance. They could take advantage of every single learning moment and experience to improve and transfer it for life learning.

\section{Conclusions and suggestions}

Challenges assumed by e-tutor when she faced in electronic environments shaped her performance positively since her students felt much more engaged with their responsibilities assumed in their course; in terms of their learning, they were provided with the necessary tools to become aware of their learning habits and became better planners of their availability. On the other hand, different roles assumed by the tutor which were at the same her challenges, expanded her students' knowledge on the platform, 
about others and their experience of being independent learners which highlight academic and social construction through interaction with technology and face-to-face lessons and in online environments.

As it was evidenced in this study, e-tutors might learn to shape their practices by analyzing e-learners' perceptions gathered from feedback forms filled continuously, so that immediate and right decisions could be made on time. As a reference of this study I want to point out a talk I gave at a teachers' conference entitled what teachers should do when becoming e-tutors of electronic environments distributed in three main headings as it is shown in figure 7 below:

Figure 7. E-tutor actions (Slide 12)

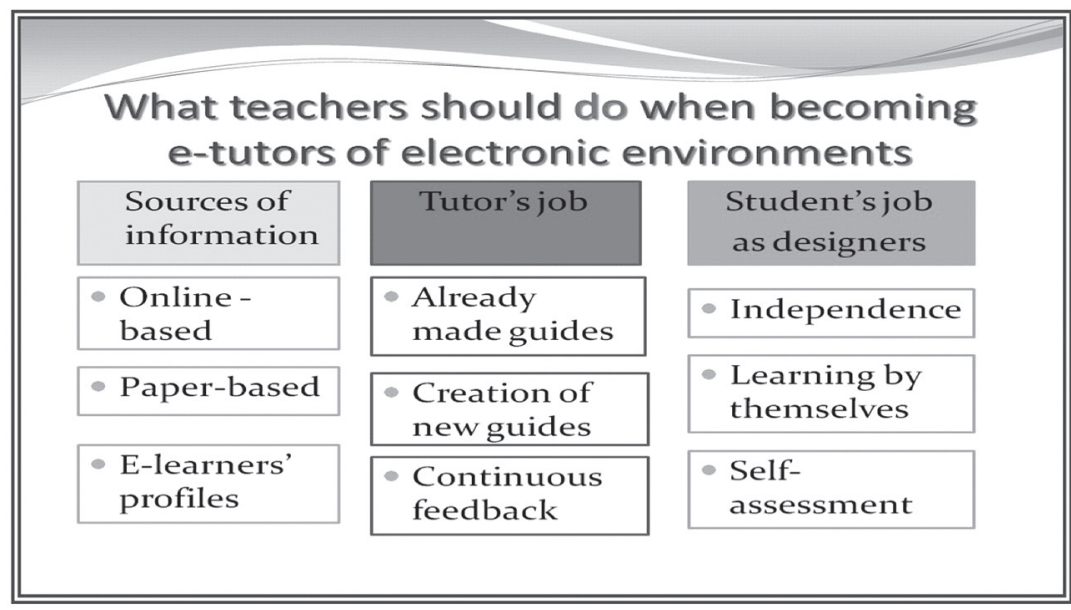

Source: Author (Slide taken from an academic talk given at the 43rd version of ASOCOPI Conference, 2008).

Moreover, transformative learning also strengthens collaborative and cooperative learning, which plays an important role in learning. Students also learnt when some group e-activities were addressed; e-learners had to cope with administrative tools such as a discussion board, chat and file exchange on the Blackboard platform, as well as some roles assignment to carry out e-activities. It was a fruitful experience because they valued what their e-partners knew about language and technology.

Through this research experience, e-tutors need to know that they are no more than the controllers of a class; they can play different roles that help e-learners improve in language performance and technological advances.

Additional suggestions were taken from transformative learning as stated by (Taylor 1998). Different types of learning can occur (independent learning, experiential learning, collaborative and cooperative learning), and the active experimentation model by Maier and Warren (2000) can support novice and experienced tutors who depart from practice; trial and error on electronic environments continues with a reflective observation from self-assessment, feedback from others, and seeing results at the time their pedagogical implementation is taking place. To finish an abstract contextualization makes sense of what they have experienced in order to integrate new knowledge and theory to their specific field. This can be replicated in academic events, as is the case of being updated in educational and technological development programs, so they can assume with confidence these new challenges in their implementations.

For beginners, these e-environments could sound unfriendly. Teachers do not have to be afraid of unknown e-experiences, and they have to learn how to be patient and brave when assuming this 
role with e-platforms. E-learners, who do not have experience with e-platforms, will need to have class sessions with some training before starting their lessons online; they need to be guided carefully through the platform tools use to avoid confusion, frustration and anxiety. Some platform tools are not easy to handle by e-learners, especially the discussion board, which requires more than one exemplification. Some navigational tours should be created and left on the platform menu, so e-learners can check them at any time when they need to resolve their doubts.

Besides, previous suggestions, nowadays tutors are invited to take some courses in advance to deal with e-learning tools. Expertise from e-tutors is requested to carry out successful e-experiences and gain confidence in the administration of these e-environments. Teachers do not have to believe that with some classes they are going to become experts, it is necessary to take more than a course or be very self-disciplined for this to be achievable.

Therefore, e-tutors are welcome to share experiences in academic events such as symposia, congresses, conferences, etc., so that they can support future e-experiences with the expertise gained from carried out experiences. Figure 8 shows a brief synthesis of some suggested steps to carry out a future e-project.

Figure 8. E-Tutor's knowledge (Slide 4

\begin{tabular}{|c|c|}
\hline \multicolumn{2}{|c|}{$\begin{array}{c}\text { What teachers should know when } \\
\text { becoming tutors of electronic } \\
\text { environments }\end{array}$} \\
\hline $\begin{array}{c}\text { A. Continuous } \\
\text { updating } \\
\text { programs }\end{array}$ & $\begin{array}{l}\text { 1. Being trained as an } \\
\text { e-tutor to handle } \\
\text { electronic } \\
\text { environments } \\
\text { 2. Carrying out e- } \\
\text { learning proposals. } \\
\text { 3. Evaluating the } \\
\text { proposal and } \\
\text { making some } \\
\text { decisions of } \\
\text { change. } \\
\text { 4. Implementing a } \\
\text { new proposal. }\end{array}$ \\
\hline
\end{tabular}

Source: Author (Slide taken from an academic talk given at the 43rd version of ASOCOPI Conference, 2008).
Regarding the role of administering the platform, it is necessary to teach e-learners how to submit their work online; this would save e-tutors time when administering and processing information, especially when using the digital drop box or messages on the Blackboard platform because it would help them systematize grading and feedback.

Finally, e-tutors need to sharpen their skills as material designers in order to engage e-learners with a fun language and technology learning practice. Make sure you create your own activities or give credit to sources of information to avoid plagiarism.

\section{References}

Burgos, D., \& Griffiths, D (2005). E-learning specifications. An introduction. Last retrieved online 8 November2008 from http://hdl.handle.net/1820/547.

Cranton, P. (1994). Understanding and promoting transformative learning: A guide for educators of adults. San Francisco, CA: Jossey-Bass.

Dudeney, G., \& Hocly, N. (2007). E-learning: online teaching and training. How to teach English with technology. Essex: Pearson Longman.

Freeman, D. (1998). Doing teacher research: from inquiry to understanding. London: Heinle and Heinle Publishers.

Goold, A., Coldwell, J., and Craig, D. (2010). An examination of the role of the e-tutor in University Australasian. Journal of Educational Technology, 26(5), 704-16.

Imel, S. (1998). Transformative Learning in Adulthood. ERIC Digest No. 200. Columbus. ERIC Clearinghouse on Adult Career and Vocational Education, Center on Education and Training for Employment, College of Education, the Ohio State University.

Kolb, D. A. (1984). Experiential Learning: experience as the source of learning andevelopment. Englewood Cliffs, NJ: Prentice Hall.

Lopez, M. (2008). What teachers should know and do when becoming tutors of electronic environments. Academic talk given at the 43 rd version of ASOCOPI Conference. UPTC. Tunja. 
Maier, P., \& Warren, A. (2000).Integr@ting Technology in Learning \& Teaching: Practical Guide for Educators. New York, NY: Routledge.

Merriam, S. (1988). Case Study Research. San Francisco. Jossey-Nass Publishers.

Nissena, E., \& Teab, E. (April, 2012). Going blended: new challenges for second generation L2 tutors. Computer Assisted Language Learning, 25(2), 145-163.

O’Neil, D. (2007). How Distance Education Has Changed Teaching and the Role of the Instructor. Proceedings ISECON. V24 (Pittsburgh). Retrieved at http://proc. isecon.org/2007/2542/ISECON.2007.ONeil.pdf on March 29, 2014.

Stickler, U., \& Hampel, R. (February, 2007). Designing online tutor training for language courses: a case study The Open University. UK Open Learning, 22(1), 75-85.

Taylor, E. W. (1998). The theory and practice of transformative learning: A critical review. Information series No 374. Columbus: ERIC Clearinghouse on Adult, Career, and Vocational Education, Center on Education and Training for Employment, College of Education, the Ohio State University.

Xiao, J. (November, 2012). Tutors' influence on distance language students' learning motivation: voices from learners and tutors. Distance Education, 33(3), 365-380. 